
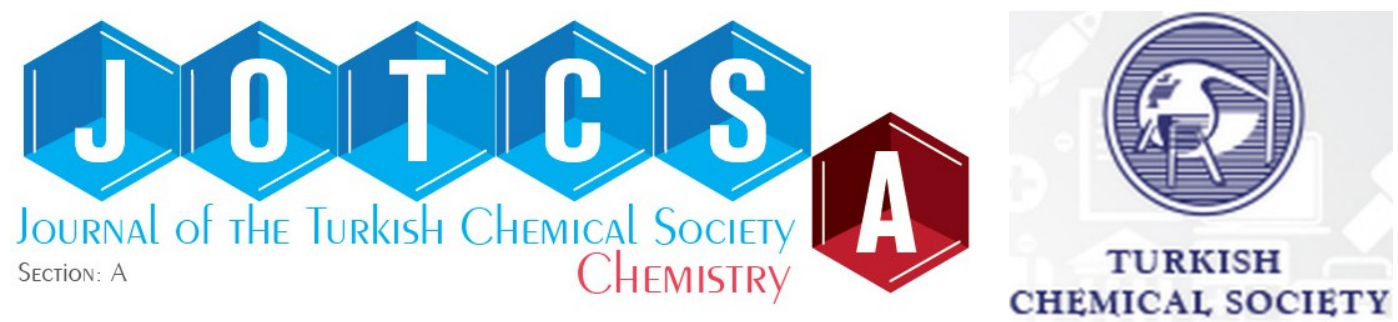

\title{
Sorption of Cobalt and Nickel on Narcissus tazetta L. Leaf Powder
}

\author{
Süleyman İnan $\triangle D$, Bekir Özkan $\triangle D$ \\ Ege University, Institute of Nuclear Sciences, İzmir, Turkey.
}

\begin{abstract}
Narcissus tazetta Linnaeus are grown in the Karaburun district of the Agean Region in Turkey in large quantities. The flower has an economic value; however, the leaves of the plant are of no use. Within this study's scope, sorption behaviors of Narcissus tazetta L. leaf powder against cobalt and nickel ions were investigated by batch experiments. The effects of initial $\mathrm{pH}$, contact time, initial metal concentration, temperature, and biosorbent dosage were examined using one-factor-at-a-time method. Maximum sorption capacities for $\mathrm{Co}$ (II) and $\mathrm{Ni}(\mathrm{II})$ were 43.48 and $35.97 \mathrm{mg} \mathrm{g}^{-1}$, respectively. The biosorption process is fast, and the equilibrium was attained in $15 \mathrm{~min}$. for $\mathrm{Co}$ (II) and $\mathrm{Ni}$ (II). Data fit the pseudo-second-order kinetic model well for both metal ions. Thermodynamic parameters reveal that the biosorption is exothermic and spontaneous. Narcissus tazetta $L$. Leaf powder is a readily available, costless, and promising biomaterial that can be used to separate $\mathrm{Co}(\mathrm{II})$ and $\mathrm{Ni}(\mathrm{II})$ ions from an aqueous solution.
\end{abstract}

Keywords: Biosorption, cobalt, nickel, Narcissus tazetta, separation.

Submitted: February 17, 2021. Accepted: May 25, 2021.

Cite this: İnan S, Özkan B. Sorption of Cobalt and Nickel on Narcissus tazetta L. Leaf Powder. JOTCSA. $2021 ; 8(3): 705-14$.

DOI: https://doi.org/10.18596/jotcsa.881291.

*Corresponding author. E-mail: inansuleyman@gmail.com.

\section{INTRODUCTION}

Industrial effluents contain a wide range of hazardous metals, including $\mathrm{Co}$ and $\mathrm{Ni}$. Among these metals, cobalt is arising from metallurgical, chloro-alkali, paint, dye, petroleum, battery industries, and coal-fired power plants and penetrates water sources (1). On the other hand, nickel-containing wastes are generated due to nickel mining, nickel plating, and battery production (2). Apart from this, ${ }^{63} \mathrm{Ni}$ and ${ }^{60} \mathrm{Co}$ are radionuclides with long half-lives formed during the nuclear energy generation, and also accumulate in the metallic parts of the core and the reactor vessel. Due to its long half-life (100 years), ${ }^{63} \mathrm{Ni}$ will remain a significant radioactivity source for 20 years after decommissioning a nuclear reactor (3). Hazardous metals have destructive effects and therefore their removal from wastewaters and the aqueous stream is vital for preserving humanity and the environment. For this reason, inexpensive, ecofriendly, and effective materials have always been the focus of attention in removing hazardous metal ions from dilute solutions $\left(1-100 \mathrm{mg} \mathrm{L}^{-1}\right)$ and for the mitigation of heavy metal ion concentration to acceptable levels.

Separation techniques such as solvent extraction, chemical precipitation, and reverse osmosis can be inefficient or very expensive (4). Biosorption is an intriguing technique often used to remove hazardous metals from various types of contaminated waste solutions. It has been reported that a significant number of biomass are used as biosorbent in removing metal ions from liquid waste. Proteins, lipids, and polysaccharides are the constituents of biomass cell walls containing hydroxyl, phosphate sulfate, carboxylate, and amino groups that can adsorb metal ions (4).

Seaweeds (5), brown algae $(2,6)$, fungi (7), rice bran (4), crab shell particles (8), plants (9), tree leaves $(1,10)$ were utilized for cobalt and nickel biosorption studies. Biosorption behaviors of six different seaweed species for $\mathrm{Co}$ (II) and $\mathrm{Ni}(\mathrm{II})$ were examined by Vijayaraghavan et al. They reported that sorption capacity of Sargassum wightii was $18.58 \mathrm{mg} \mathrm{g}^{-1}$ for $\mathrm{Ni}(\mathrm{II})$ at $\mathrm{pH} 4$ and $20.63 \mathrm{mg} \mathrm{g}^{-1}$ for 
$\mathrm{Co}(\mathrm{II})$ at $\mathrm{pH} 4.5$ (5). Biosorption studies of $\mathrm{Ni}(\mathrm{II})$ ions were carried out using 4 types of brown algae by Pahlavanzadeh et al. $\mathrm{Ni}$ (II) biosorption was optimized at $\mathrm{pH} 6$ for all types of algae. The maximum $\mathrm{Ni}(\mathrm{II})$ uptake was found as $55.56 \mathrm{mg} \mathrm{g}^{-1}$ for Sargassum glaucescens (2). Zafar et al. analyzed the influence of $\mathrm{pH}$, biosorbent size and dosage, initial concentration, and time on $\mathrm{Ni}(\mathrm{II})$ sorption using protonated rice bran. It was reported that the $\mathrm{Ni}$ (II) removal was rapid, and $57 \%$ of sorption took place between 15-30 min. $\mathrm{Ni}(\mathrm{II})$ uptake was $102 \mathrm{mg} \mathrm{g}^{-1}$ at $\mathrm{pH} 6$ (4).

Narcissus is the common name of the plant species from the Amaryllidaceae family of the Narcissus genus. The homeland of these plants is Europe, and the richest species is found in Spain and Portugal (11). Narcissus tazetta is the name of the genus particularly grown in the Karaburun district of the Agean Region in Turkey. Flowers are harvested in the winter period, and afterward, leaves coming out of bulbs starts to dry. During the summer period, they become totally dry. Dried leaves have no use, and they are considered as biowaste. The utilization of Narcissus tazetta $L$. leaf powder for the biosorption of $\mathrm{Eu}(\mathrm{III})$ ions has been reported by Inan and Özkan (12). It is noteworthy to investigate the separation and removal potential of this novel biomaterial for hazardous ions.

In this study, we aimed to examine Narcissus tazetta $L$. leaf powder's biosorption behaviors for cobalt and nickel removal from aqueous media. The biosorbent was characterized, and batch tests were performed to assess the parameters affecting Co(II) and $\mathrm{Ni}(\mathrm{II})$ sorption.

\section{EXPERIMENTAL SECTION}

\section{Materials}

$\mathrm{Co}\left(\mathrm{NO}_{3}\right)_{2} \cdot 6 \mathrm{H}_{2} \mathrm{O}, \quad \mathrm{Ni}\left(\mathrm{NO}_{3}\right)_{2} \cdot 6 \mathrm{H}_{2} \mathrm{O}$, Co and $\mathrm{Ni}$ calibration standards for Inductively Coupled Plasma-Optical Emission Spectrometer (ICP-OES) (1000 $\mathrm{mg} \mathrm{L}^{-1}$ ), nitric acid and ammonia solution were supplied from Sigma-Aldrich, Germany. 1000 $\mathrm{mg} \mathrm{L}^{-1}$ stock solutions of cobalt and nickel were prepared with dissolving $4.94 \mathrm{~g}$ and $4.95 \mathrm{~g}$ of cobalt nitrate hexahydrate and nickel nitrate hexahydrate in $1 \mathrm{~L}$ distilled water, respectively.

\section{Preparation of Biosorbent}

Dry Narcissus tazetta $L$. leaves were collected from a flower garden in Karaburun district (38०40'9.97"N, 26²6'24.61"E), İzmir province (Turkey) in June 2018. The leaves were kept in the oven at $50{ }^{\circ} \mathrm{C}$ for $72 \mathrm{~h}$ and ground in a mortar. The ground leaf powders were sieved, and the fraction between $0.125 \mathrm{~mm}$ and $0.250 \mathrm{~mm}$ were used in batch experiments.

\section{Characterization Studies}

The infrared spectrum of Narcissus tazetta $L$. leaf powder was acquired before and after biosorption by Fourier Transform Infrared-Attenuated Total Reflectance (FTIR-ATR) spectrometer (Perkin Elmer Spectrum Two) between 550 and $4000 \mathrm{~cm}^{-1}$. Brunauer-Emmett-Teller (BET) surface area and porosity measurements of leaf powders were taken at $77 \mathrm{~K}$ by a surface area analyzer (Micromeritics ASAP 2020). Before measurements, powders were degassed at $323 \mathrm{~K}$ under vacuum for $72 \mathrm{~h}$. BET and Barrett-Joyner-Halenda $(\mathrm{BJH})$ methods were employed to calculate surface area and pore characteristics of Narcissus tazetta L. leaf powder, respectively.

\section{Batch Experiments}

Batch tests were employed to find out the effects of sorption parameters on $\mathrm{Co}$ (II) and $\mathrm{Ni}$ (II) biosorption. The stock solutions were diluted and the desired concentrations of test solutions (25 $600 \mathrm{mg} \mathrm{L}^{-1}$ ) were obtained. The $\mathrm{pH}$ adjustments of solutions were done by using nitric acid and ammonia.

For each run, liquid and solid phases were contacted in a temperature controlled shaker (GFL 1086) at $130 \mathrm{rpm}$. Each parameter's effect was determined by alteration of one variable at a time while others were kept constant. The experimental conditions under investigation were provided in Table 1.

Table 1: Experimental conditions under investigation.

\begin{tabular}{ll}
\hline Parameter & Value \\
\hline Initial pH & $2,3,4,5,6,7$ \\
Contact time $(t), \min$ & $1,5,15,30,60,120$ \\
Initial metal concentration $\left(C_{0}\right), \mathrm{mg} \mathrm{L}^{-1}$ & $25,50,100,200,400,600$ \\
Temperature $(T), \mathrm{K}$ & $303,313,323$ \\
Biosorbent dosage $(w), \mathrm{g} \mathrm{L}^{-1}$ & $0.4,1,2,4,8$ \\
\hline
\end{tabular}

At the equilibrium, the liquid phase was separated from the biosorbent using quantitative filter paper.
$\mathrm{Co}$ (II) and $\mathrm{Ni}$ (II) concentrations were determined by ICP-OES (Perkin Elmer Optima 2000DV). Uptake 
capacity ( $\mathrm{mg} \mathrm{g}^{-1}$ ) and biosorption efficiency (\%) were calculated as given in Eqs. (1) and (2), respectively.

$$
\begin{gathered}
\text { Uptake capacity }(Q)=\left(C_{0}-C_{e}\right) \times \frac{V}{m} \\
\text { Biosorption efficiency }(\%)=\frac{C_{0}-C_{e}}{C_{0}} \times 100
\end{gathered}
$$

where $C_{o}$ and $C_{e}$ are the initial and equilibrium concentrations of $\mathrm{Co}$ (II) and $\mathrm{Ni}$ (II) ions $\left(\mathrm{mg} \mathrm{L}^{-1}\right), V$ is the solution volume $(\mathrm{mL})$ and $m$ is the mass of the biosorbent $(\mathrm{g})$.

\section{RESULTS AND DISCUSSION}

\section{Surface Analyses}

Data on surface area and pore properties were collected for $0.125-0.250 \mathrm{~mm}$ particle size. BET surface area and $\mathrm{BJH}$ adsorption cumulative pore volume of leaf powders were measured as $1.725 \pm$ $0.0988 \mathrm{~m}^{2} \mathrm{~g}^{-1}$ and $0.00252 \mathrm{~cm}^{3} \mathrm{~g}^{-1}$, respectively.
The majority of pores have an average diameter of $1.75 \mathrm{~nm}$; however, there are few pores with an average diameter between 5 and $100 \mathrm{~nm}$.

\section{FT-IR Analysis}

FTIR curves as shown in Figure 1 of the raw and metal sorbed form of the biosorbent are almost similar except for a slight alteration in some peaks' intensity. The peak around $3337 \mathrm{~cm}^{-1}$ indicates $-\mathrm{OH}$ stretching vibrations of hydroxyl containing functional groups (13), and two peaks at 2917 and $2849 \mathrm{~cm}^{-1}$ refer to $-\mathrm{CH}$ stretching vibrations (14). A peak at $1732 \mathrm{~cm}^{-1}$ shows the $\mathrm{C}=\mathrm{O}$ stretching of ketones and carboxylic acids whereas the peak at $1608 \mathrm{~cm}^{-1}$ demonstrates the asymmetrical $\mathrm{C}=\mathrm{O}$ stretching of COO- groups (15). The peaks at 1245 $\mathrm{cm}^{-1}$ and $1020 \mathrm{~cm}^{-1}$ can be the indicator of $\mathrm{O}-\mathrm{H}$ stretching in phenol group and C-O stretching, respectively.

\section{The Effect of Initial pH}

$\mathrm{Co}$ (II) and $\mathrm{Ni}$ (II) uptake capacity with the change in initial $\mathrm{pH}$ was assessed in the $\mathrm{pH}$ range $2-7$ (Figure 2). Experiments above $\mathrm{pH} 7$ were not conducted due to the risk of metal hydrolysis.

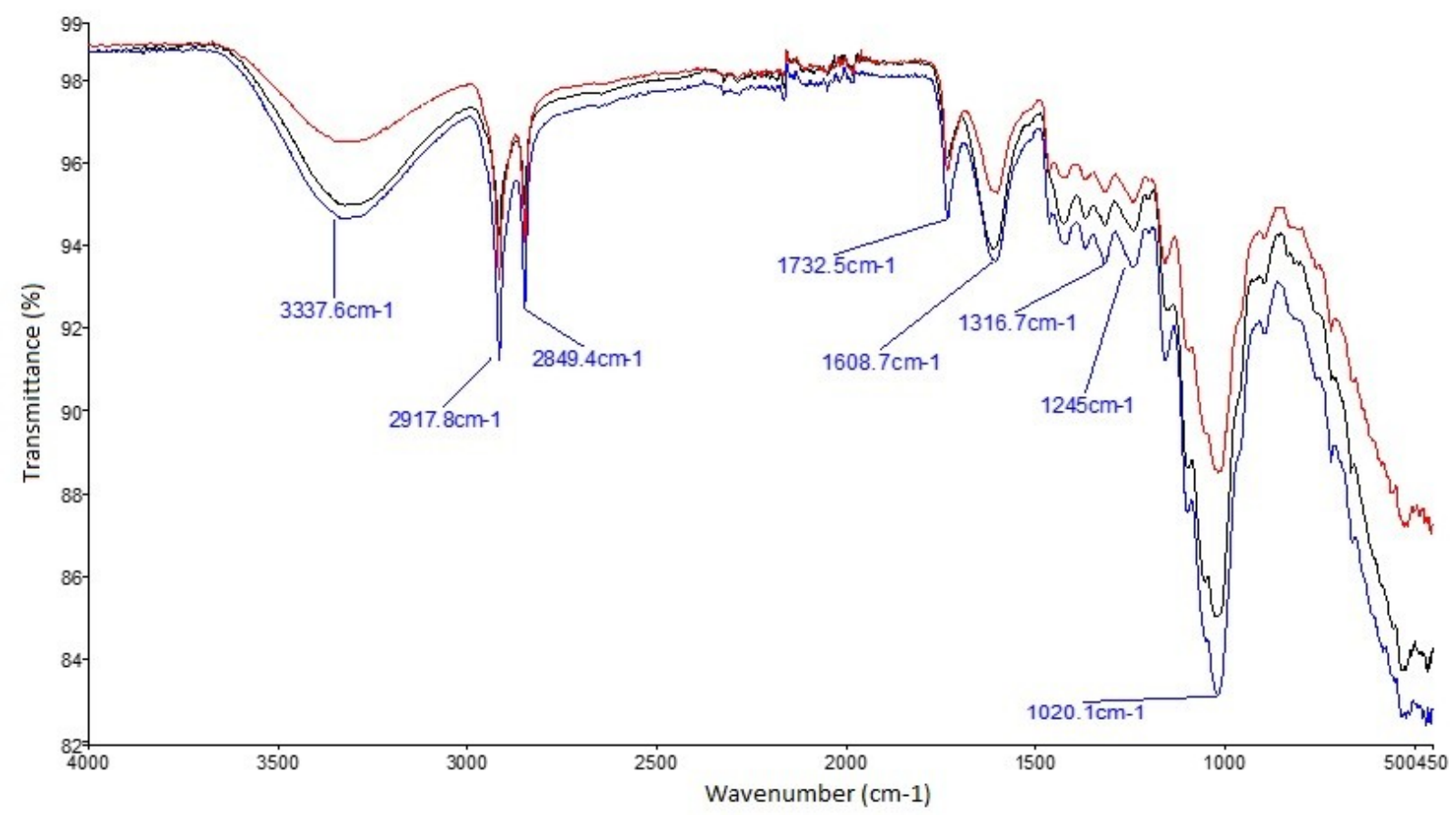

Figure 1: Infrared spectra of Narcissus tazetta L. leaf powder before and after biosorption: before sorption (black), after $\mathrm{Co}(\mathrm{II})$ sorption (red), after $\mathrm{Ni}(\mathrm{II})$ sorption (blue). 


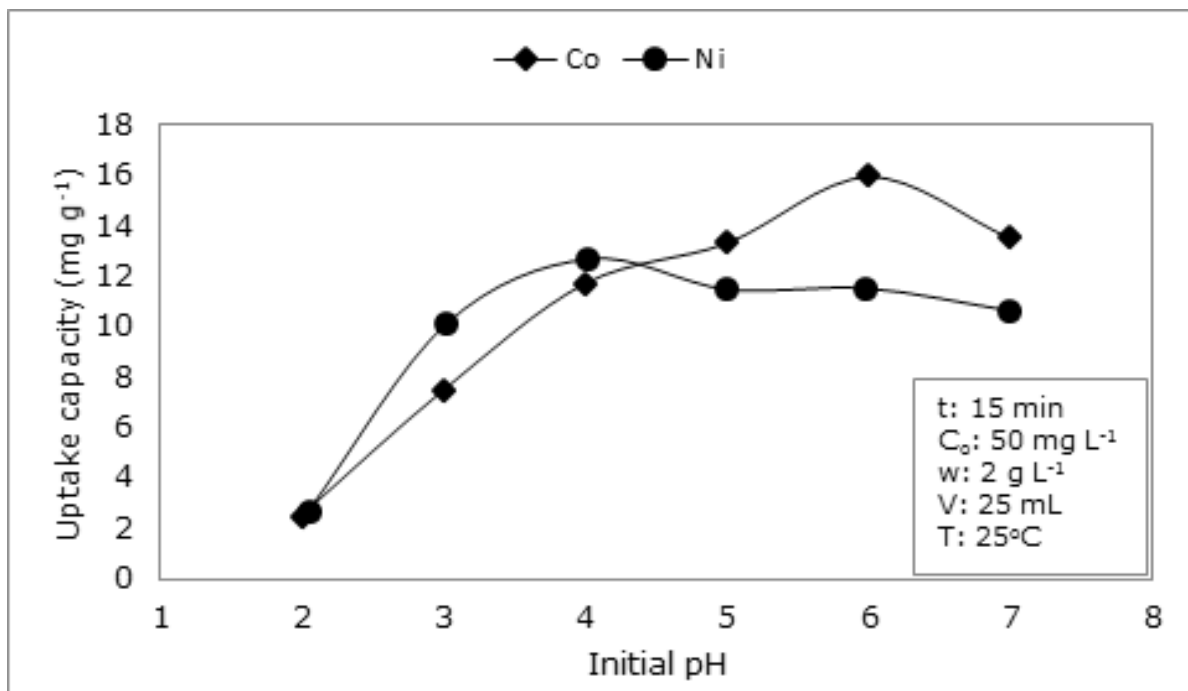

Figure 2: Change in $\mathrm{Co}(\mathrm{II})$ and $\mathrm{Ni}(\mathrm{II})$ uptake capacity with initial $\mathrm{pH}$.

A gradual increase in $\mathrm{Co}$ (II) uptake capacity up to $\mathrm{pH} 6$ is seen. Maximum $\mathrm{Co}$ (II) uptake capacity of $15.98 \mathrm{mg} \mathrm{g}^{-1}$ was reached. After $\mathrm{pH} \mathrm{6,} \mathrm{Co(II)}$ uptake capacity tends to decrease. Biosorption of cobalt using Sargassum glaucescens nanoparticles was investigated by Esmaeili and Beni. The optimum $\mathrm{Co}$ (II) sorption capacity was found at $\mathrm{pH} 6$ (6).

On the other hand, $\mathrm{Ni}(\mathrm{II})$ uptake follows an increasing trend up to $\mathrm{pH} 4$, and at this point, $\mathrm{Ni}$ (II) uptake was $12.71 \mathrm{mg} \mathrm{g}^{-1}$. Between $\mathrm{pH} 4$ and 7, $\mathrm{Ni}$ (II) uptake capacity decreases slightly. Vijayaraghavan et al. reported that Sargassum wightii had a $\mathrm{Ni}(\mathrm{II})$ uptake of $18.58 \mathrm{mg} \mathrm{g}^{-1}$ at $\mathrm{pH} 4$ (5).

\section{The Effect of Contact Time}

Figure 3 represents the variation of metal uptake on Narcissus tazetta $L$. leaf powder depending on contact time. It is clearly seen that the sorption was fast, and the sorption equilibrium was established in 15 min for both $\mathrm{Co}$ (II) and $\mathrm{Ni}(\mathrm{II})$. At the end of 15 min, uptake capacities were obtained as 11.43 and $10.15 \mathrm{mg} \mathrm{g}^{-1}$ for $\mathrm{Co}(\mathrm{II})$ and $\mathrm{Ni}(\mathrm{II})$, respectively. No significant change was determined after 15 min of contact. Similar data were reported by Akar et al. (16) where nickel(II) uptake on silica-gelimmobilized waste biomass increased up to $20 \mathrm{~min}$, and no considerable change was observed after this time. Fast biosorption kinetics of $\mathrm{Co}$ (II) and $\mathrm{Ni}$ (II) on Narcissus tazetta $L$. leaf powder could be interpreted by the abrupt filling of the easily accessible sites on the cell wall of the biosorbent.

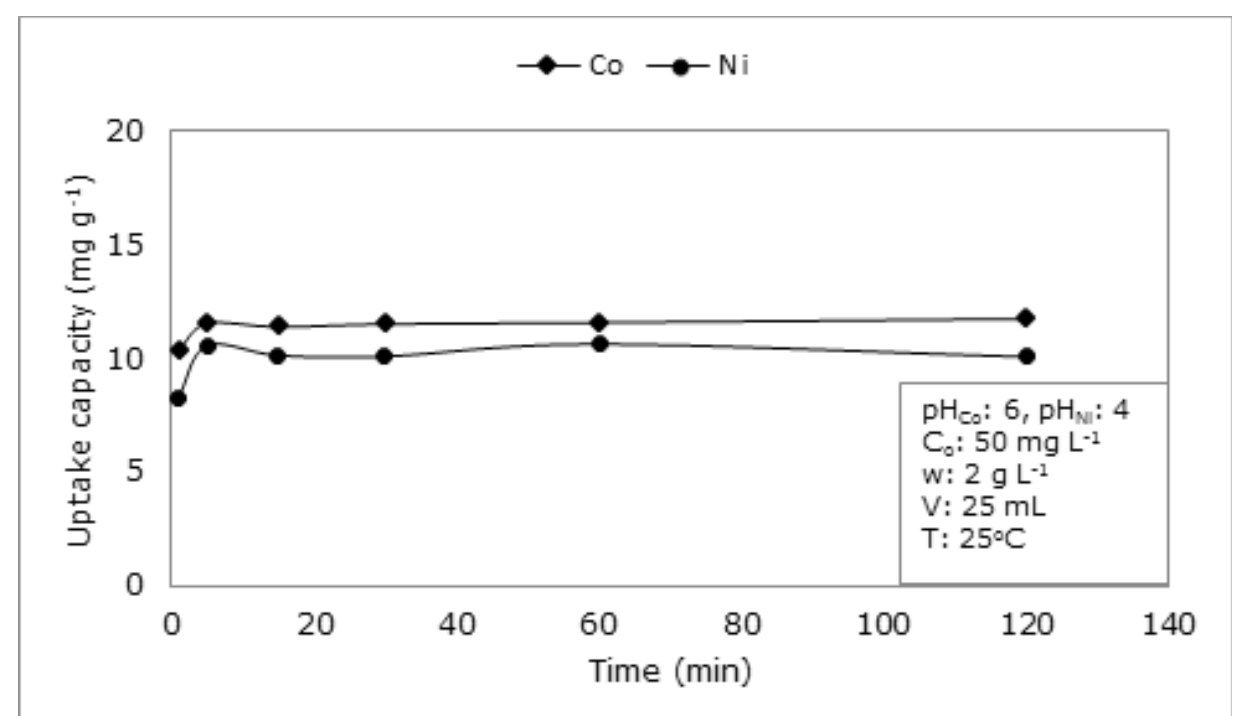

Figure 3: Influence of contact time on $\mathrm{Co}(\mathrm{II})$ and $\mathrm{Ni}(\mathrm{II})$ uptake capacity. 
Experimental kinetic data were interpreted by empirical models. Pseudo-first order model (Eq.(3)) and its linear form (Eq.(4)) are presented below:

$$
\begin{aligned}
& \frac{d q_{t}}{d t}=k_{1}\left(q_{e}-q_{t}\right) \\
& \ln \left(q_{e}-q_{t}\right)=\ln q_{e}-k_{1} t
\end{aligned}
$$

where $k_{1}$ is the rate constant $\left(\mathrm{min}^{-1}\right), q_{e}$ and $q_{t}$ are the quantity of metal uptake per unit mass of sorbent ( $\mathrm{mg} \mathrm{g}^{-1}$ ) at equilibrium and at time $t$, respectively (17-19). Using the slope and intercept values of the graph, $k_{1}$ and $q_{e}$ were obtained. The experimental data can not, however, be explained well with the pseudo-first order model due to the relatively low $R^{2}$ values and the fact that calculated $\mathrm{q}_{\mathrm{e}}$ values are not in accordance with the experimental data.

The pseudo-second order model (20) is associated with the capacity of sorbent. The model (Eq. (5)) and its linear form (Eq. (6)) are given below:

$$
\begin{aligned}
& \frac{d q_{t}}{d_{t}}=k_{2}\left(q_{e}-q_{t}\right) \\
& \frac{t}{q_{t}}=\frac{1}{k_{2} q_{e}^{2}}+\frac{t}{q_{e}}
\end{aligned}
$$

where $k_{2}$ is the second order rate constant $\left(\mathrm{g} \mathrm{mg}^{-1}\right.$ $\left.\mathrm{min}^{-1}\right)$. The second-order model parameters were provided in Table 2 . Correlation coefficient $\left(R^{2}\right)$ values point out that $\mathrm{Co}$ (II) and $\mathrm{Ni}$ (II) biosorption can be explained well with second-order equation.

\section{The Effect of Initial Concentration}

The effect of initial concentration was presented in Figure 4. Co(II) uptake increased from 5.88 to $35.80 \mathrm{mg} \mathrm{g}^{-1}$ with an increase in the initial $\mathrm{Co}$ (II) concentration from 25 to $200 \mathrm{mg} \mathrm{L}^{-1}$. After $200 \mathrm{mg}$ $\mathrm{L}^{-1}$ of initial concentration, $\mathrm{Co}$ (II) uptake capacity of biosorbent reached a plateau and was almost constant. For $\mathrm{Ni}$ (II) uptake, a gradual increase can be seen up to $400 \mathrm{mg} \mathrm{L}^{-1}$. After $400 \mathrm{mg} \mathrm{L}^{-1}$, the rate of increase slowed down, and it can be interpreted that the filling of active zones on the biosorbent has started.

Table 2: Second-order kinetic data.

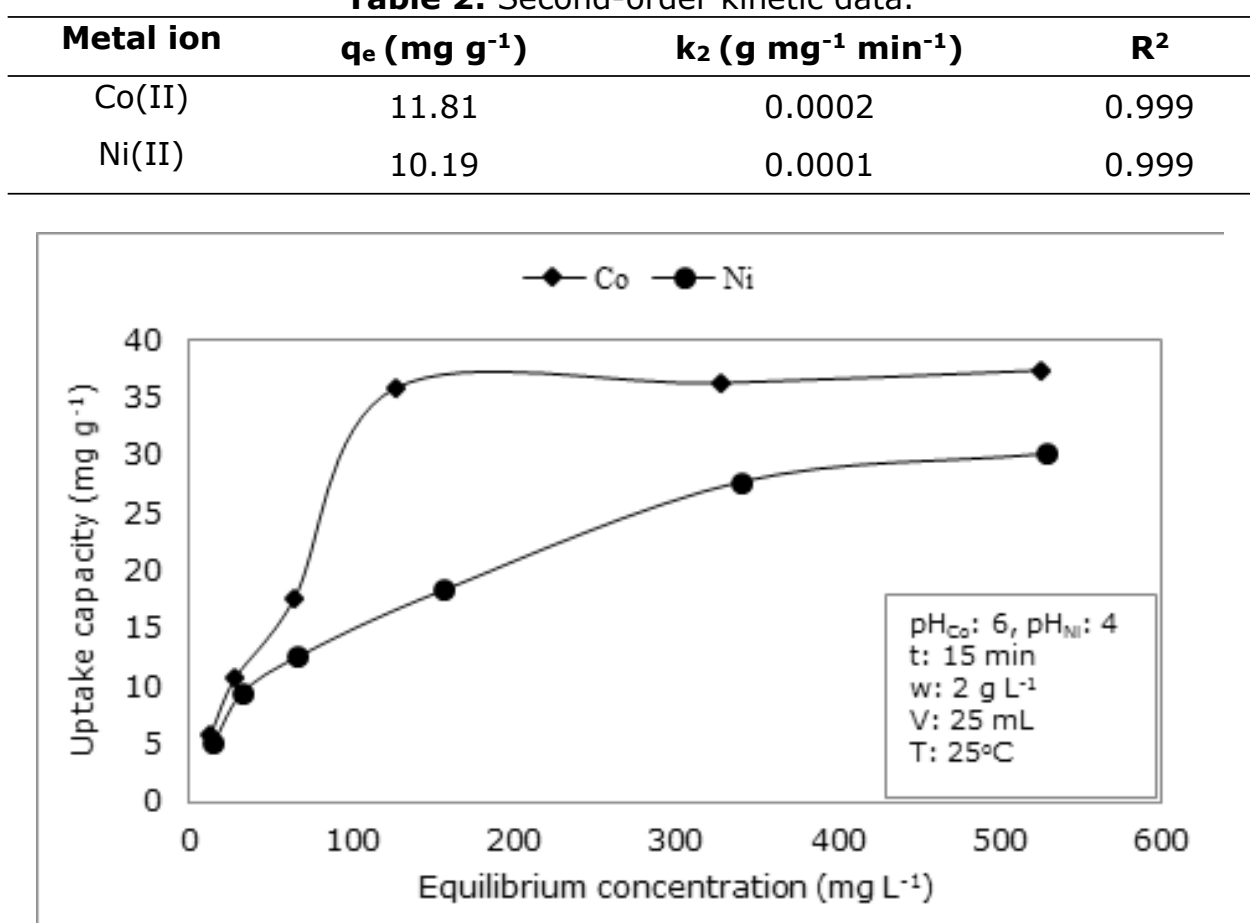

Figure 4: Variation of $\mathrm{Co}(\mathrm{II})$ and $\mathrm{Ni}$ (II) uptake capacity with initial concentration.

Isotherms interpret the sorption equilibrium and provide data on the amount of metal ion on sorbent phase and in the solution. According to Langmuir's theory, sorption occurs in certain homogeneous regions on the sorbent surface. Langmuir equation (21) is written as follows:

$$
\frac{C_{e}}{q_{e}}=\frac{1}{q_{m}^{b}}+\frac{C_{0}}{q_{m}}
$$

where $q_{m}$ is the maximum quantity of the metal per unit mass of sorbent $\left(\mathrm{mg} \mathrm{g}^{-1}\right), C_{e}$ is the equilibrium 
concentration (mg L $\mathrm{L}^{-1}$ ), and $b$ is a constant associated with sorption energy $\left(\mathrm{L} \mathrm{mg}^{-1}\right)$.

Table 3 presents the obtained $q_{m}, b$, and $\mathrm{R}^{2}$ values. High $\mathrm{R}^{2}$ values indicate that the sorption of both metals could be explained well by the Langmuir model.

Separation factor $\left(R_{L}\right)$ is a dimensionless constant expressed by Webber and Chakkravorti (22). It is derived from the Langmuir model and is calculated as in Eq. (8):

$$
R_{L}=\frac{1}{1+b C_{0}}
$$

where $b$ is the constant from Langmuir equation ( $L$ $\mathrm{mg}^{-1}$ ), and $C_{o}$ is initial metal ion concentration ( $\mathrm{mg}$ $\left.\mathrm{L}^{-1}\right)$. The sorption is considered favorable if the calculated value of $R_{L}$ is between zero and one $(0<$ $\left.R_{L}<1\right)$. The variation of $R_{L}$ values with initial Co(II) and $\mathrm{Ni}$ (II) concentration was plotted as illustrated in Figure 5. The biosorption was favorable in the whole concentration range under investigation.

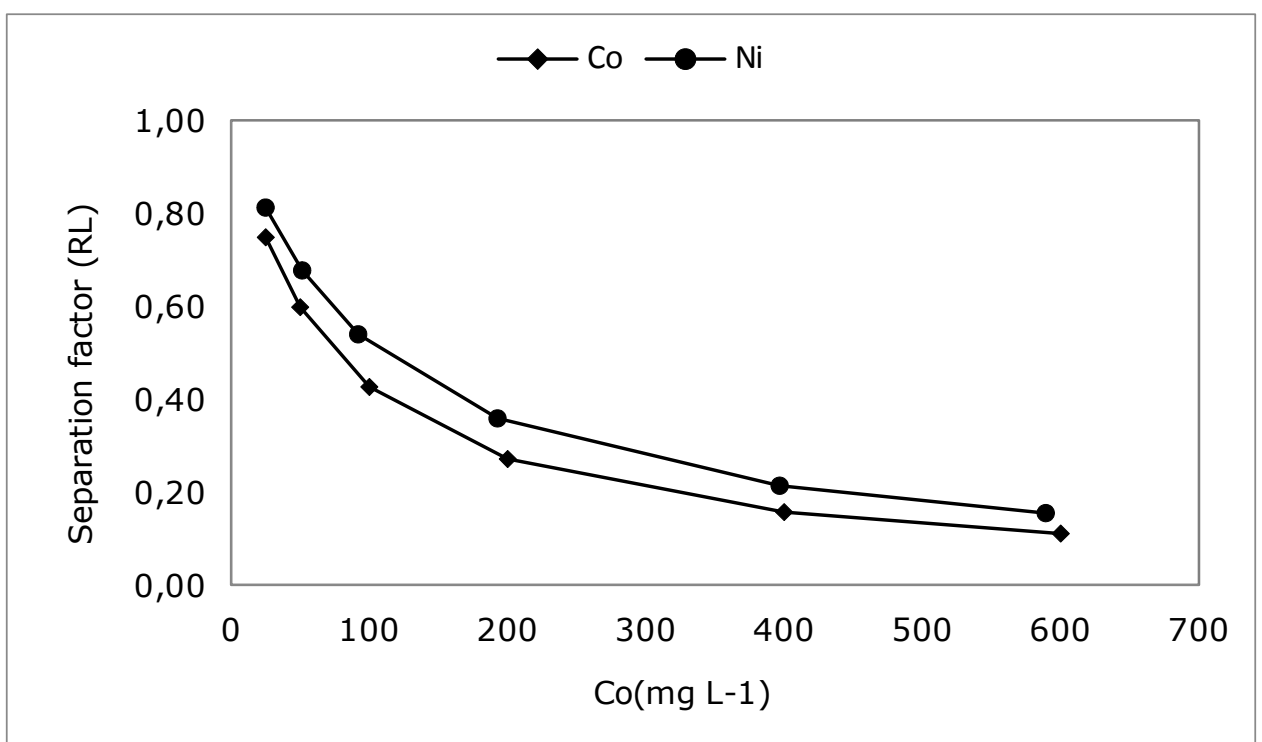

Figure 5: Variation of separation factor depending on the initial metal concentration.

Freundlich adsorption isotherm are represented as in Eqs. (9) and (10):

$$
\begin{gathered}
q_{e}=K_{f} C_{e}^{\frac{1}{n}} \\
\ln q_{e}=\ln K_{f}+\frac{1}{n} \ln C_{e}
\end{gathered}
$$

where $q_{e}$ is the metal uptake per unit mass of the sorbent at equilibrium $\left(\mathrm{mg} \mathrm{g}^{-1}\right), C_{e}$ is the equilibrium concentration, $K_{f}$ is the constant related to adsorption capacity and $n$ is the constant of adsorption intensity. Freundlich isotherm parameters are shown in Table 3. If we examine the $\mathrm{R}^{2}$ values, we can deduce that the biosorption data do not fit the Freundlich isotherm well.

Dubinin-Radushkevich (D-R) equation is described as in Eq. (11):

$$
\ln q_{e}=\ln q_{m}-\beta \epsilon^{2}
$$

$\varepsilon$, the Polanyi potential is given by Eq. (12):

$$
\epsilon=R T \ln \left(1+\frac{1}{C_{e}}\right)
$$

where $\beta$ is the mean free energy constant $\left(\mathrm{mol}^{2} \mathrm{~J}^{2}\right)^{-}$ $1, q_{e}$ is the quantity of metal sorbed at equilibrium (mg g-1), $q_{m}$ is the theoretical saturation capacity (mg g $\left.\mathrm{g}^{-1}\right), T$ is the temperature $(\mathrm{K})$ and $R$ is the gas constant. The adsorption mean free energy $E(\mathrm{~kJ}$ $\mathrm{mol}^{-1}$ ) is obtained as follows:

$$
E=\frac{1}{\sqrt{(2 \beta)}}
$$

When the $\mathrm{E}$ value is below $8 \mathrm{~kJ} \mathrm{~mol}^{-1}$, the sorption process can be considered as physical sorption. If the $\mathrm{E}$ value is within $8-16 \mathrm{~kJ} \mathrm{~mol}^{-1}$, the mechanism is chemical sorption. $D-R$ isotherm data are summarized in Table 3. E value for both metal ions was obtained as $0.10 \mathrm{~kJ} \mathrm{~mol}^{-1}$. These values indicate that physical sorption plays a dominant role in both biosorption processes.

The maximum $\mathrm{Co}(\mathrm{II})$ and $\mathrm{Ni}(\mathrm{II})$ uptake $\left(q_{m}\right)$ values of various biosorbents are illustrated in Table 4 . It was determined that the maximum uptake 
capacities obtained for $\mathrm{Co}(\mathrm{II})$ and $\mathrm{Ni}(\mathrm{II})$ in the present study were higher than most of the values found in similar studies.

\section{The Effect of Temperature}

Metal uptake slightly decreased with temperature variation from 303 to $323 \mathrm{~K}$ (Figure 6). The obtained results revealed that the alteration of temperature determined no remarkable impact on metal uptake. When the temperature shifted from 303 to $323 \mathrm{~K}, \mathrm{Co}$ (II) and $\mathrm{Ni}$ (II) uptake decreased from $10.42 \mathrm{mg} \mathrm{g}^{-1}$ to $9.63 \mathrm{mg} \mathrm{g}^{-1}$ and from 10.80 $\mathrm{mg} \mathrm{g}^{-1}$ to $10.11 \mathrm{mg} \mathrm{g}^{-1}$, respectively.

Table 3: Langmuir, Freundlich and $\mathrm{D}-\mathrm{R}$ isotherm parameters for $\mathrm{Co}(\mathrm{II})$ and $\mathrm{Ni}(\mathrm{II})$ biosorption on Narcissus tazetta $L$. leaf powder.

\begin{tabular}{|c|c|c|c|c|c|c|c|c|c|}
\hline & \multicolumn{3}{|c|}{ Langmuir } & \multicolumn{3}{|c|}{ Freundlich } & \multicolumn{3}{|c|}{ D-R } \\
\hline & $\mathrm{q}_{\mathrm{m}}\left(\mathrm{mg} \mathrm{g}^{-1}\right)$ & $\mathrm{b}\left(\mathrm{L} \mathrm{mg}^{-1}\right)$ & $\mathrm{R}^{2}$ & $\mathrm{~K}_{\mathrm{f}}$ & $\mathrm{n}$ & $\mathrm{R}^{2}$ & $\mathrm{q}_{\mathrm{m}}\left(\mathrm{mg} \mathrm{g}^{-1}\right)$ & $\mathrm{E}\left(\mathrm{kJ} \mathrm{mol}^{-1}\right)$ & $\mathrm{R}^{2}$ \\
\hline $\mathrm{Co}$ (II) & 43.48 & 0.014 & 0.985 & 1.917 & 1.941 & 0.899 & 27.89 & 0.10 & 0.753 \\
\hline $\mathrm{Ni}(\mathrm{II})$ & 35.97 & 0.009 & 0.987 & 1.617 & 2.082 & 0.984 & 19.85 & 0.10 & 0.721 \\
\hline
\end{tabular}

Table 4: Cobalt and nickel ion uptake $\left(q_{m}\right)$ data of various biosorbents.

\begin{tabular}{|c|c|c|c|}
\hline Biosorbent & $\begin{array}{l}\text { Maximum Cobalt } \\
\text { Uptake }\left(\mathrm{mg} \mathrm{g}^{-1}\right)\end{array}$ & $\begin{array}{l}\text { Maximum Nickel } \\
\text { Uptake }\left(\mathrm{mg} \mathrm{g}^{-1}\right)\end{array}$ & Reference \\
\hline $\begin{array}{l}\text { Ficus Religiosa } \\
\text { leaf powder }\end{array}$ & 3.60 & - & $(1)$ \\
\hline $\begin{array}{l}\text { Protonated rice } \\
\text { bran }\end{array}$ & - & 46.51 & (4) \\
\hline $\begin{array}{l}\text { Sargassum } \\
\text { glaucescens }\end{array}$ & 10.11 & 28.73 & (6) \\
\hline $\begin{array}{l}\text { Modified } \\
\text { Aspergillus flavus }\end{array}$ & 31.06 & 32.26 & (7) \\
\hline $\begin{array}{l}\text { Crab Shell } \\
\text { Particles }\end{array}$ & 322.6 & - & (8) \\
\hline $\begin{array}{l}\text { Cone biomass of } \\
\text { Thuja orientalis }\end{array}$ & - & 12.42 & (23) \\
\hline $\begin{array}{l}\text { Black carrot } \\
\text { residues }\end{array}$ & 5.350 & 5.745 & (24) \\
\hline Coir pith & 12.82 & 15.95 & (25) \\
\hline $\begin{array}{l}\text { Narcissus tazetta } \\
\text { L. Leaf Powder }\end{array}$ & 43.48 & 35.97 & Present Study \\
\hline
\end{tabular}

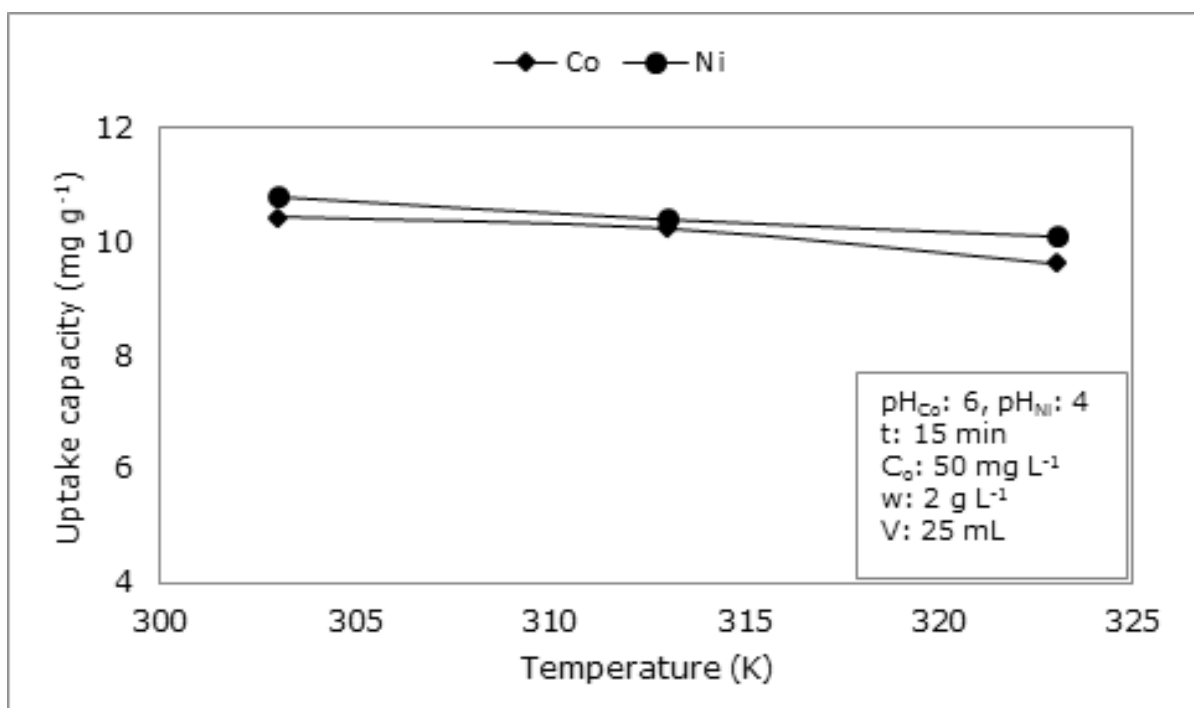

Figure 6: Influence of temperature on uptake capacity.

Thermodynamic data provides information about the spontaneity of the biosorption process. The enthalpy
$\left(\Delta H^{\circ}\right)$, entropy $\left(\Delta S^{\circ}\right)$ and Gibbs free energy $\left(\Delta G^{\circ}\right)$ 
changes were estimated using Eqs. (14), (15) and (16) (26).

$$
\begin{aligned}
& K_{D}=\frac{C_{0}-C_{e}}{C_{e}} \times \frac{V}{m} \\
& \ln K_{D}=\frac{\Delta S^{0}}{R}-\frac{\Delta H^{0}}{R T} \\
& \Delta G^{0}=\Delta H^{0}-T \Delta S^{0}
\end{aligned}
$$

where $K_{D}$ is the thermodynamic equilibrium constant $\left(\mathrm{mL} \mathrm{g}^{-1}\right), T$ is the temperature $(\mathrm{K}), R$ is the universal gas constant $\left(8.314 \mathrm{~J} \mathrm{~mol}^{-1} \mathrm{~K}^{-1}\right), V$ is the solution volume $(\mathrm{mL})$, and $m$ is the mass $(\mathrm{g})$ of the biosorbent. From the slope and intercept of Van't Hoff plot (InK $K_{D}$ versus $1 / T$ ) $\Delta \mathrm{H}^{\circ}$ and $\Delta \mathrm{S}^{\circ}$ values were obtained.

Thermodynamic data concerning $\mathrm{Co}(\mathrm{II})$ and $\mathrm{Ni}(\mathrm{II})$ biosorption are presented in Table $5 . \Delta G^{\circ}$ values were found negative at 303,313 , and $323 \mathrm{~K}$, indicating that the biosorption process was spontaneous for both metal ions.

The negative $\Delta \mathrm{H}^{\circ}$ value denotes that biosorption is an exothermic process. The positive $\Delta S^{\circ}$ value points out the increase in disorder with the flow of $\mathrm{Co}(\mathrm{II})$ and $\mathrm{Ni}(\mathrm{II})$ ions towards the sorbent surface. Generally, $\Delta G^{\circ}$ values for physical sorption are from - 20 to $0 \mathrm{~kJ} \mathrm{~mol}^{-1}$, while chemisorption occurs in the range of -80 to $-400 \mathrm{~kJ} \mathrm{~mol}^{-1}$ (27). $\Delta \mathrm{G}^{\circ}$ values obtained in the present study support that the mechanism involved in biosorption is physical sorption.

\section{The Effect of Biosorbent Dosage}

As shown in Figure 7, $\mathrm{Co}$ (II) 's biosorption efficiency (\%) increased from 21.06 to $45.30 \%$ with the variation of biosorbent dosage from 0.4 to $4.0 \mathrm{~g} \mathrm{~L}^{-1}$.

Similar behavior was observed for $\mathrm{Ni}(\mathrm{II})$ ions. An increase in the biosorption efficiency(\%) from 25.35 to $43.52 \%$ could be seen with the variation of

\begin{tabular}{|c|c|c|c|c|c|}
\hline \multirow[t]{2}{*}{ Ions } & \multirow[t]{2}{*}{$\Delta H^{\circ}\left(\mathrm{kJ} \mathrm{mol}^{-1}\right)$} & \multirow[t]{2}{*}{$\Delta S^{\circ}\left(\mathrm{kJ} \mathrm{mol}^{-1} \mathrm{~K}^{-1}\right)$} & \multicolumn{3}{|c|}{$\Delta G^{\circ}\left(\mathrm{kJ} \mathrm{mol}^{-1}\right)$} \\
\hline & & & $303 \mathrm{~K}$ & $313 \mathrm{~K}$ & $323 \mathrm{~K}$ \\
\hline $\mathrm{Co}(\mathrm{II})$ & -5.62 & 0.031 & -15.013 & -15.023 & -15.633 \\
\hline $\mathrm{Ni}(\mathrm{II})$ & -4.35 & 0.035 & -14.955 & -15.305 & -15.655 \\
\hline
\end{tabular}
biosorbent dosage in the same range.

Table 5: Thermodynamic data for $\mathrm{Co}(\mathrm{II})$ and $\mathrm{Ni}(\mathrm{II})$ biosorption.

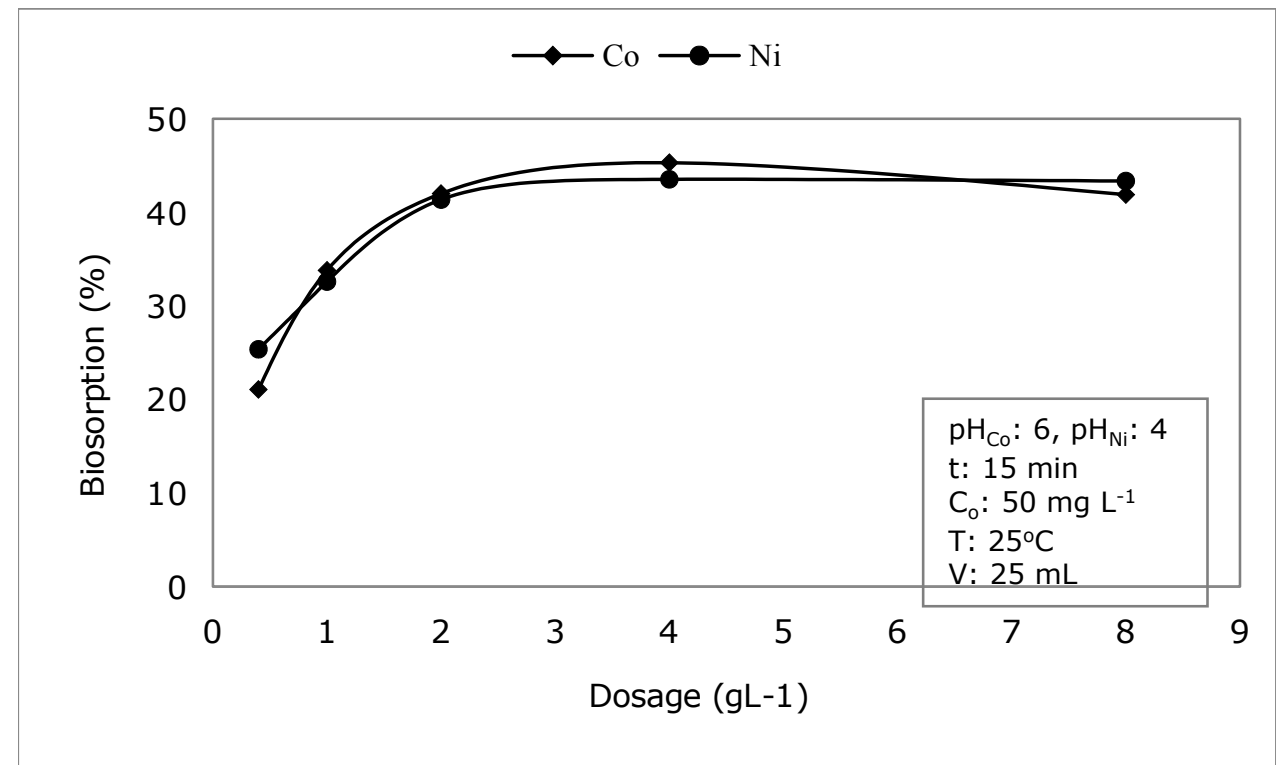

Figure 7: Effect of biosorbent dosage on biosorption efficiency (\%).

\section{CONCLUSION}

In this study, novel biomaterial biosorption behaviors, Narcissus tazetta L. leaf powder towards $\mathrm{Co}(\mathrm{II})$ and $\mathrm{Ni}(\mathrm{II})$ ions, were investigated. The maximum $\mathrm{Co}$ (II) and $\mathrm{Ni}$ (II) uptake were obtained at $\mathrm{pH} 6$ and $\mathrm{pH} 4$, respectively. The biosorption process was rapid, and the equilibrium was achieved in $15 \mathrm{~min}$ for both metal ions. Biosorption kinetics fit the pseudo-second-order model well. The sorption isotherm data were best explained by Langmuir isotherm. The monolayer $\mathrm{Co}(\mathrm{II})$ and $\mathrm{Ni}(\mathrm{II})$ sorption capacities were 43.48 and $35.97 \mathrm{mg} \mathrm{g}^{-1}$, respectively. It has been determined that temperature does not have a significant impact on biosorption. The thermodynamic parameters 
evaluation revealed that the $\mathrm{Co}$ (II) and $\mathrm{Ni}(\mathrm{II})$ biosorption processes were exothermic and spontaneous. When the biosorbent dosage increased in the range of $0.2-4.0 \mathrm{~g} \mathrm{~L}^{-1}$, biosorption efficiency (\%) of $\mathrm{Co}(\mathrm{II})$ and $\mathrm{Ni}(\mathrm{II})$ increased from 21.06 to $45.30 \%$ and 25.35 to $43.52 \%$, respectively. Overall results indicate that the removal of $\mathrm{Co}$ (II) and $\mathrm{Ni}$ (II) from dilute solutions by Narcissus tazetta L. leaf powder, which is costless and readily available in vast amount, is promising.

\section{ACKNOWLEDGEMENTS}

The authors would like to thank Ms. Dilara Yörür, Ms. Ezgi Çelik, and Mr. Ümit Emre Kartal for their contribution in the laboratory.

\section{REFERENCES}

1. Krishna B, Venkateswarlu P. Influence of Ficus religiosa leaf powder on bisorption of cobalt. Ind J Chem Technol. 2011 Sep;18:381-90.

2. Pahlavanzadeh $\mathrm{H}$, Keshtkar AR, Safdari J, Abadi Z. Biosorption of nickel(II) from aqueous solution by brown algae: Equilibrium, dynamic and thermodynamic studies. Journal of Hazardous Materials. 2010 Mar;175(1-3):304-10. DOI: https://doi.org/10.1016/j.jhazmat.2009.10.004.

3. Koivula R, Harjula R, Lehto J. $63 \mathrm{Ni}$ and 57 Co Uptake and Selectivity of Tin Antimonates of Different Structure. Separation Science and Technology. 2003 Jan 10;38(15):3795-808. DOI: https://doi.org/10.1081/SS-120024231.

4. Zafar MN, Nadeem R, Hanif MA. Biosorption of nickel from protonated rice bran. Journal of Hazardous Materials. 2007 May;143(1-2):478-85. DOI:

https://doi.org/10.1016/j.jhazmat.2006.09.055.

5. Vijayaraghavan $\mathrm{K}$, Jegan J, Palanivelu K, Velan $\mathrm{M}$. Biosorption of cobalt(II) and nickel(II) by seaweeds: batch and column studies. Separation and Purification Technology. 2005 Jul;44(1):53-9. DOI: https://doi.org/10.1016/j.seppur.2004.12.003.

6. Esmaeili A, Aghababai Beni A. Biosorption of nickel and cobalt from plant effluent by Sargassum glaucescens nanoparticles at new membrane reactor. Int J Environ Sci Technol. 2015 Jun;12(6):2055-64. DOI: https://doi.org/10.1007/s13762-014-0744-3.

7. Foroutan R, Esmaeili $\mathrm{H}$, Rishehri SD, Sadeghzadeh F, Mirahmadi S, Kosarifard M, et al. Zinc, nickel, and cobalt ions removal from aqueous solution and plating plant wastewater by modified Aspergillus flavus biomass: A dataset. Data in Brief. 2017 Jun; 12:485-92. DOI:

https://doi.org/10.1016/j.dib.2017.04.031.
8. Vijayaraghavan $\mathrm{K}$, Palanivelu $\mathrm{K}$, Velan $\mathrm{M}$. Biosorption of copper(II) and cobalt(II) from aqueous solutions by crab shell particles. Bioresource Technology. 2006 Aug;97(12):1411-9. DOI: https://doi.org/10.1016/j.biortech.2005.07.001.

9. Tounsadi H, Khalidi A, Abdennouri M, Barka N. Biosorption potential of Diplotaxis harra and Glebionis coronaria L. biomasses for the removal of $\mathrm{Cd}$ (II) and $\mathrm{Co}$ (II) from aqueous solutions. Journal of Environmental Chemical Engineering. 2015 Jun;3(2):822-30. DOI:

https://doi.org/10.1016/j.jece.2015.03.022.

10. Prasad MNV, Freitas H. Removal of toxic metals from solution by leaf, stem and root phytomass of Quercus ilex L. (holly oak). Environmental Pollution. 2000 Nov; $110(2): 277-83$.

https://doi.org/10.1016/S0269-7491(99)00306-1.

11. Hanks GR. Commercial production of Narcissus bulbs. In: Narcissus and Daffodil. London: Taylor and Francis; 2002. p. 53-130.

12. İnan S, Özkan B. Eu (III) 'un Narcissus Tazetta L. Yaprak Tozu Üzerine Biyosorpsiyonu. Deu Muhendislik Fakultesi Fen ve Muhendislik. 2019 Sep 20;21(63):955-66. DOI:

https://doi.org/10.21205/deufmd.2019216324.

13. Brigante M, Zanini G, Avena M. Effect of humic acids on the adsorption of paraquat by goethite. Journal of Hazardous Materials. 2010 Dec;184(13):241-7. DOI:

https://doi.org/10.1016/j.jhazmat.2010.08.028.

14. Fu H, Quan X. Complexes of fulvic acid on the surface of hematite, goethite, and akaganeite: FTIR observation. Chemosphere. 2006 Apr;63(3):40310. DOI:

https://doi.org/10.1016/j.chemosphere.2005.08.05 4.

15. Wei W, Yang L, Zhong W, Cui J, Wei Z. Mechanism of enhanced humic acid removal from aqueous solution using poorly crystalline hydroxyapatite nanoparticles. Digest Journal of Nanomaterials and Biostructures. 2015;10(2):66380 .

16. Akar T, Kaynak Z, Ulusoy S, Yuvaci D, Ozsari G, Akar ST. Enhanced biosorption of nickel(II) ions by silica-gel-immobilized waste biomass: Biosorption characteristics in batch and dynamic flow mode. Journal of Hazardous Materials. 2009 Apr;163(23):1134-41. DOI:

https://doi.org/10.1016/j.jhazmat.2008.07.084. 
17. Lagergren S. About the theory of so-called adsorption of solution substances. $1898 ; 24(4)$ : 14756.

18. Ho YS, McKay G. Sorption of dye from aqueous solution by peat. Chemical Engineering Journal. 1998 Jun;70(2):115-24. DOI: https://doi.org/10.1016/S0923-0467(98)00076-1.

19. Ho YS, McKay G. The sorption of dye from aqueous solution by peat. Water Res. 1999; 33(2): 578-84. DOI: https://doi.org/10.1016/S09230467(98)00076-1.

20. Mahajan G, Sud D. Kinetics and equilibrium studies of $\mathrm{Cr}(\mathrm{VI})$ metal ion remediation by Arachis hypogea shells: A green approach. BioResources. 2011;6(3):3324-38. URL:

https://ojs.cnr.ncsu.edu/index.php/BioRes/article/d ownload/BioRes 0633324 Mahajan S Kinetic So rption Cr6 Arachis/1121.

21. Langmuir I. The adsorption of gases on plane surfaces of glass, mica and platinum. J Am Chem Soc. 1918 Sep;40(9):1361-403. DOI: https://doi.org/10.1021/ja02242a004.

22. Weber TW, Chakravorti RK. Pore and solid diffusion models for fixed-bed adsorbers. AIChE J. 1974 Mar;20(2):228-38. DOI: https://doi.org/10.1002/aic.690200204.

23. Malkoc $\mathrm{E}$. $\mathrm{Ni}$ (II) removal from aqueous solutions using cone biomass of Thuja orientalis. Journal of
Hazardous Materials. 2006 Sep 21;137(2):899-908. DOI:

https://doi.org/10.1016/j.jhazmat.2006.03.004.

24. Guzel F, Yakut H, Topal G. Determination of kinetic and equilibrium parameters of the batch adsorption of $\mathrm{Mn}$ (II), $\mathrm{Co}(\mathrm{II}), \mathrm{Ni}$ (II) and $\mathrm{Cu}$ (II) from aqueous solution by black carrot (Daucus carota L.) residues. Journal of Hazardous Materials. 2008 May 30;153(3):1275-87. DOI:

https://doi.org/10.1016/j.jhazmat.2007.09.087.

25. Parab H, Joshi S, Shenoy N, Lali A, Sarma US, Sudersanan $M$. Determination of kinetic and equilibrium parameters of the batch adsorption of $\mathrm{Co}(\mathrm{II}), \mathrm{Cr}(\mathrm{III})$ and $\mathrm{Ni}(\mathrm{II})$ onto coir pith. Process Biochemistry. 2006 Mar;41(3):609-15. DOI: https://doi.org/10.1016/j.procbio.2005.08.006.

26. Nayak AK, Pal A. Green and efficient biosorptive removal of methylene blue by Abelmoschus esculentus seed: Process optimization and multivariate modeling. Journal of Environmental Management. 2017 Sep;200:145-59. DOI: https://doi.org/10.1016/j.jenvman.2017.05.045.

27. Gerçel Ö, Özcan A, Özcan AS, Gerçel HF. Preparation of activated carbon from a renewable bio-plant of Euphorbia rigida by $\mathrm{H} 2 \mathrm{SO} 4$ activation and its adsorption behavior in aqueous solutions. Applied Surface Science. 2007 Mar;253(11):484352. DOI:

https://doi.org/10.1016/j.apsusc.2006.10.053. 